\title{
Community habitats and biodiversity in the Taburno-Camposauro Regional Park. Woodland, rare species, endangered species and their conservation
}

\author{
Guarino $C^{*}$, Napolitano F \\ Dipartimento di Scienze Biologiche ed Ambientali, Università degli Studi del Sannio, v. Port'Arsa, 11 - 82100 Be- \\ nevento (BN) - *Corresponding author: Carmine Guarino (guarino@unisannio.it).
}

\begin{abstract}
Community habitats and biodiversity in the Taburno-Camposauro Regional Park. Woodland, rare species, endangered species and their conservation. The Taburno-Camposauro Regional Park is an area of major natural interest in the region of Campania (southern Italy): it represents a protected area isolated from the main axis of the Campanian Apennines, including two sites of community importance (SCIs - ITA8020007 - ITA8020008) covering about $75 \%$ of the whole area. The present study aims to identify and describe the community habitats and forest biodiversity in the park, as well as to provide suggestions for their conservation. By a large survey carried out from March 2004 to October 2005, nine community-interest habitats were identified, five of which are priority habitats. Some 26 tree forest species and 971 other plant species including grasses and shrubs were also identified and classified, 14 of which are listed in the red data book of plants. As conservation of each species is strictly linked to the conservation of its habitat, on the basis of legislation in force at regional, national and EU levels, management guidelines were drawn up for the various habitat types and for the most endangered species in order to ensure biodiversity conservation.
\end{abstract}

Keywords: Habitat, Endemism, Rare species, Biodiversity, Nature management.

Received: Jun 09, 2006 - Accepted: Nov 06, 2006.

Citation: Guarino C, Napolitano F, 2006. Community habitats and biodiversity in the Taburno-Camposauro Regional Park. Woodland, rare species, endangered species and their conservation. Forest@ 3 (4): 527-541. [online] URL: http://www.sisef.it/.

\section{Introduction}

During the '80s the World Conservation Strategy has emphasised three main ways through which the complex of protected areas may contribute to habitat conservation: 1) supporting the conservation of populations of threatened species and their natural ecosystems; 2) providing the support and the structures required to enhance scientific knowledge from which conservation may benefit; 3 ) promoting greater awareness of the need to conserve nature, using natural resources sustainably and establishing the right equilibrium between mankind and nature.

Nowadays, several motivations underlay the institution of protected natural areas, that may be summarised as follows: a) nature conservation; b) use by society; c) economic development; d) cultural dissemination. Italian laws focus on objectives of nature conservation and biological diversity which may maintain the ecological equilibria between the various structural elements in the region, its biological components and functions that regulate it and permit its actions. The law is the advanced result of complex reworking of many previous laws which have been revisited and applied from a modern standpoint, overcoming the short-sighted view from the past of protected areas being exclusive concepts. Indeed, the new frontiers of environmental policy are oriented towards "active conservation": the aim is not to take parts of the region apart from the public, but rather to elevate them to the status of "expansion areas" for the local economy through a new nature policy consisting of integrated and sustainable area management. This national law has been followed by regional laws; in Campania the regional 


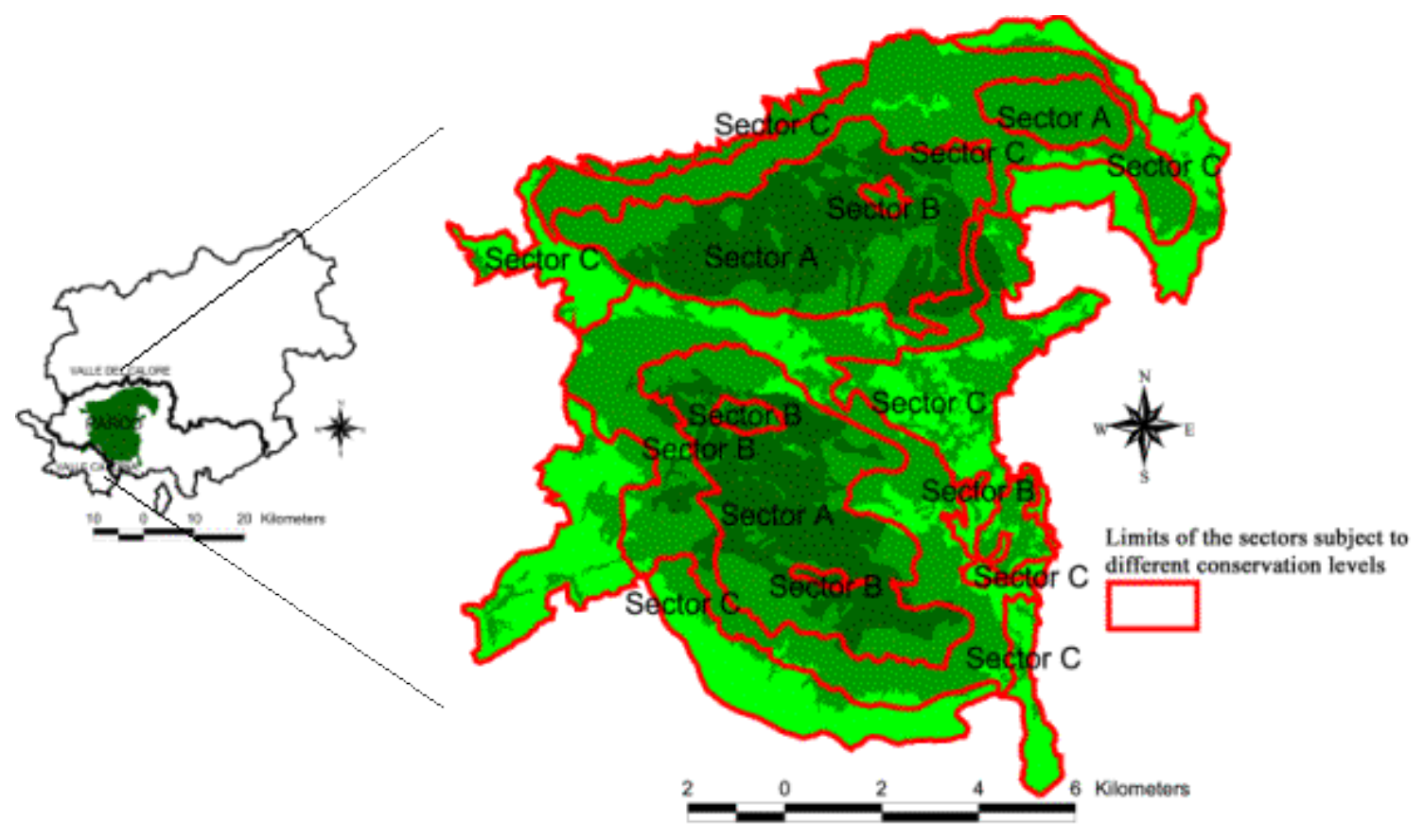

Fig. 1 - Geographic location of the Taburno-Camposauro Regional Park within the province of Benevento (southern Italy).

parks have been established by the Law n 33 of 1993 on the "establishment of parks and nature reserves in Campania" (BURC 1993).

The protection and the conservation of forest biodiversity is therefore fundamental for regional development as it affects major socio-economic processes and maintains strong links with other key environmental issues. On the other hand, applying protection strategies and criteria is a difficult issue, in that an accurate environmental analysis on endangered species and ongoing processes is needed.

The Taburno-Camposauro Regional Park is an area of major natural interest in the region of Campania (southern Italy): it represents a protected area which is isolated from the main axis of the Campanian Apennines, and includes also two sites of community importance (SCIs - ITA8020007 - ITA8020008) covering about $75 \%$ of the whole area. This study aims to identify and describe the community habitats and the forest biodiversity in the park, and indicate guidelines for their conservation.

\section{Materials and methods}

\section{Description of the area}

The Taburno-Camposauro Regional Park was identified by Regional Law no. 33 of 1/09/1993 and was established by Campania Regional Authority no. 671 of $10 / 09 / 2002$. It covers an area of $137.8 \mathrm{~km}^{2}$ having a sub-elliptical perimeter with four extensions: a) in the southern sector the town of Sant'Agata de' Goti (SW) and Montesarchio (SE); b) in the western sector, the town of Melizzano; c) in the eastern sector, the town of Cautano (Fig. 1).

Although the Taburno-Camposauro Regional Park takes its name from the two highest mountains, it does not cover completely the two reliefs: the northern part does not include all the slopes of Mt. Camposauro. The Taburno-Camposauro massif consists of two large Dolomitic-limestone tectonically overlapping layers. The two massifs have different origins and lithology: the Taburno mountain group consists of Dolomitic limestones dating back to the Triassic, Jurassic and Cretaceous and belonging to the Alburno-Cervati units of the Campano-Lucanian carbonatic platform; Mt. Camposauro consists mainly of carbonatic sediments that may be ascribed to the Jurassic-Cretaceous, belonging to the MateseMonte Maggiore units of the Abruzzese-Campanian platform (D'Argenio 1963, D'Argenio 1967).

The park is located in a mountain area separated from the main Apennine axis. Maximum elevation within the park is reached by the Mt. Taburno (1394 $\mathrm{m}$ a.s.1.) and the Mt. Camposauro (1390 m). Peaks are separed by karstic plains and valleys like Piano Melaino, Campo, Campo Cepino, Piana di Prata; the latter, strecthing along the E-W axis, is the geomorphological element separating the two highest peaks. 
Fig. 2 - Average temperature and rainfall recorded at Montesarchio (source: Hydrologic Annals 1969-1999. U.M.O. of Naples).

\section{Bagnouls-Gaussen Diagramme}

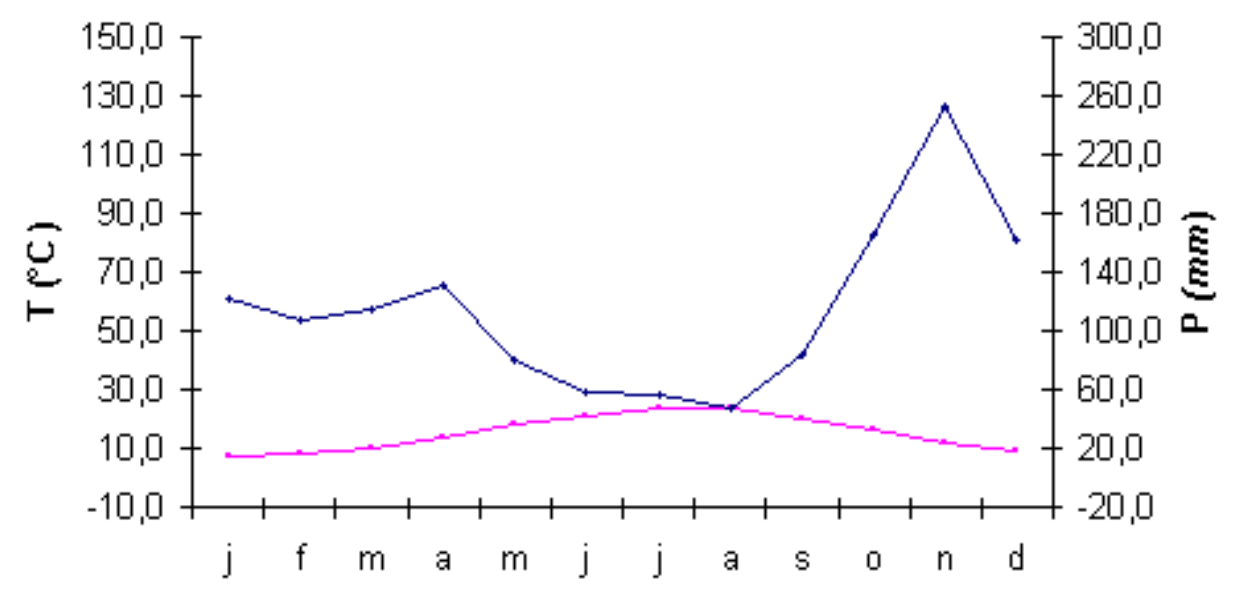

Due to its geological nature, the carbonatic massif has steep slopes and rugged morphology (limestone rocks with near-vertical walls are sometimes occurs).

Mean annual rainfall in the area is $1585 \mathrm{~mm}$ (Hydrologic Annals - Ufficio Mareografico e Oceanografico di Napoli), with mean summer rainfall of 153 $\mathrm{mm}$, mean winter rainfall $390 \mathrm{~mm}$ and mean annual temperature $15.1^{\circ} \mathrm{C}$. The hottest month is July with mean monthly of greatest temperatures of $36^{\circ} \mathrm{C}$ while the coldest month is January with mean monthly of lowest temperatures of $-2.7^{\circ} \mathrm{C}$. The area is affected by only slight summer drought in August (Fig. 2).

\section{Vegetation survey}

In 2004 an in-depth study was launched on the environmental inventory of the protected area of the province of Benevento. The whole area investigated was split into squares $(1 \mathrm{~km} \times 1 \mathrm{~km})$ based on the grid reported on the I.G.M. (Istituto Geografico Militare) maps at scale of 1:25000. Habitat types within each square were identified by overlapping the grid onto the vegetation map of the area considered (Guarino \& Napolitano 2003). For vegetation survey, some 46 areas falling within the park boundaries were randomly selected across squares and habitat types. Flora and vegetation surveying was carried out between March 2004 and October 2005 (18 months), and field observations were mapped using a GIS software.

Community habitats were classified based on the descriptions reported in the Annex A of the DPR no. 357 of 8 September 1997 (GU n.248 of 23/10/1997). For the types of natural habitats identified we used the codes reported in the Interpretation Manual of
European Habitats (EUR15/2 1999). The codes marked by an asterisk indicate priority habitats.

All the species recorded in the field were classified according to Pignatti's (1982), Tutin et al. (1993) nomenclature and the specific historical flora literature was also consulted (Tenore 1838, Tenore 1942, Terracciano 1878, Trotter 1907, Caputo 1968, Guarino et al. 2003). According to the red book of endangered species (Conti et al. 1997) and the List of Protected Italian flora (Ministero dell' Ambiente 2001) two different lists were drew up, for endangered species and for protected species, respectively. The latter are species occurring in small populations, with a very limited distribution, often localised or punctiform. For these species the abundance of the population and the environmental characteristics of their habitats were reported, and guidelines for a conservation strategy were also described. Moreover, a complete list of endemic species (Pignatti 1982), orchids and rare species found within the park was also drew up.

To evaluate the biodiversity of rare species, we calculated the rarity index (IR - Blana 1980, Gotmark et al. 1986, Mingozzi \& Brandmayr 1991, Lapini et al. 1994), while for habitats Shannon's diversity index $(\mathrm{H})$ and the evenness index $\left(\mathrm{E}_{\mathrm{SH}}\right)$ were used. The formula for the rarity index is:

$$
I R=1-\left(\frac{n}{N}\right) \cdot 100
$$

where $n$ is the number of squares in which the species was found and $N$ the total number of squares surveyed. The index ranges from 0 to 100. A species is rare when the index is greater than or equal to 78.08 and lower than 95; very rare, when the value is 
between 95 and 97; extremely rare, when it is greater than 97.

The formula for Shannon's index is:

$$
H^{\prime}=-\sum_{i=1}^{S} p_{i} \ln p_{i}
$$

where $p_{i}$ is the relative abundance of the $i$-th habitat given by the ratio $n_{i} / N$ where $n_{i}$ is the number of the habitats of the $i$-th category, $N$ is the total number of habitats and $S$ is the total number of habitat types; $\ln$ is the natural logarithm. When Shannon's index is close to 0 , then there are few types of habitats, one of which is strongly dominant, while for high values (up to infinity) are expected for areas with large number of habitats. In an environmental system with a finite number $S$ of habitat types, Shannon's index cannot be greater than $H_{\max }=\ln S$. Thus, to obtain a measure of the distribution of habitat types, Shannon's evenness index was calculated according to the formula:

$$
E_{S H}=\frac{-\sum p_{i} \ln p_{i}}{\ln S}
$$

where $\ln S$ is the diversity that would be obtained if habitat types $S$ had exactly the same surface area. Thus we obtain a result on a scale of values from a minimum of 0 and a maximum of 1 . The evenness index tends to zero when there are few habitats, one of which is largely dominant. It tends to one when the areas covered by each habitat are the same.

Finally, we drew up the dominance-diversity graph for the nine habitats where the dominance of each habitat is expressed in percentage. The $x$ axis shows the type of habitat (rank) and the $y$ axis gives the expressed abundance on a logarithmic scale (natural logarithm).

The conservation strategies were developed from the current regulations regarding conservation under Regional Law no. 33 of 1993 (BURC no. 39, 1993), Law no. 394 of 1991 (G.U. no. 292, 1991), DPR no. 357/1997 (G.U. no. 248, 1997) and EC Directive 92/43 (G.U.L. no. 206, 1992) and consulting the "Manual of guidelines for drawing up management plans for nature sites 2000" (Ministero dell'Ambiente 2000), given that there are two SCI areas in the park.

\section{Description of the plant communities}

\section{Meadows and pastures}

The vegetation of the meadows above the beechwood belt is well-adapted to grow on highlydrained, fairly thin, pebbly limestone soils, with strong periodic winds, directly affected by snow (which appears in mid November and melts in mid Winter). Environmental conditions are thus particularly selective. However, the main limiting factor here is grazing: the park hosts many herds of cattle which causes a considerable stress for the herbaceous species by trampling and uprooting. Nevertheless, the plant community in these area is fairly rich, hosting the rarest species of the park with a punctiform distribution, like the extremely rare Pseudolysimachion spicatum (L.) Opiz (growing in a single stand at the top of the southern slope of Mt. Taburno), as well as the orchids abundantly occurring on the same vegetational plane (e.g., Gymnadenia conopsea (L.) R. Br., Orchis papilionacea L., Orchis ustulata L., Orchisprovincialis Balbis. Orchis x colemanii Cortesi, Anacamptis pyramidalis (L.) L.C.M. Richard and in the wetter pastures Orchis mascula L.). The mullein species Verbascum niveum Ten. subsp. garganicum (Ten.) Murb is fairly rare, while the following species are found fairly frequently: Verbascum thapsus L. subsp. thapsus, Verbascum longifolium Ten., Euphrasia stricta D. Wolff., Rhinanthus minor L.

On pebbly soils the following species were found: Scrophularia canina L. subsp. canina, Chaenorhinum minus (L.) Lange subsp. minus., Ajuga chamaepytis (L.) Schreber subsp. chamaepytis, Convolvulus cantabrica L., Campanula glomerata L. subsp. glomerata, Leontodon hirtus L., Cynoglossum montanum L., Vicianarbonensis L., Ophrys sphegodes Miller subsp. sphegodes, Inula montana L., the endemic Festucarobustifolia Markgr.- Dannenb., Poa pratensis L., Poa bulbosa L., Cynosurus echinatus L., Brizamaxima L., Vulpia geniculata (L.) Link, Vulpia myuros (L.) C. C. Gmelin, Melica ciliata L. subsp. ciliata, Bromus rigidus Roth., Bromus erectus Hudson subsp. erectus, Bromus squarrosus L., Aegilops geniculata Roth, Avenula praetutiana (Parl.) Pignatti, Koeleria splendens C. Presl, Brachypodium pinnatum P.Beauv., Poa pratensis L., Calamagrostis epigejos (L.) Roth., Scilla autumnalis L., Teucrium montanum L., Thymus longicaulis C. Presl. subsp. longicaulis.

In upland areas with frequent rocky outcrops, species less preferred by grazing livestock were found, though some species with a very limited distribution may occur, namely Globularia neapolitana O. Schwarz, Plantago subulata L., Ranunculus millefoliatus Vahl, Ranunculus garganicus Ten., Globularia punctata Lapeyr., Orobanche caryophyllacea Sm., Plantago argentea Chaix, Knautia calycina (C. Presl.) Guss., Campanula tanfanii Podl., Micropus erectus L. subsp. erectus, Senecio apenninus Tausch, Carduus macrocephalus Desf. subsp. macrocephalus, Onopordum acanthium L. subsp. 
acanthium, Centaurea solstitialis L. subsp. solstitialis, Centaurea triumfetti All. subsp. triumfetti, Lactuca perennis L., Colchicum alpinum DC., Psilurus incurvus (Gouan) Schinz et Thell., Arrhenantherum elatius (L.) J. et C. Presl subsp. elatius. Some isolated trees of Fagussylvatica L. and shrubs like Ilex aquifolium L. were also found. The orchid species list includes Gymnadenia conopsea (L.) R. Br., Orchis tridentata Scop., Orchis simia Lam., Orchis ustulata L., Orchis provincialis Balbis, Orchis pauciflora Ten., Orchis x colemanii Cortesi, Ophrys fuciflora (F.W. Schmidt) Moench, Ophrys sphegodes Miller subsp. sphegodes.

The most common species noticed in this landscape unit were Carlina acaulis L. subsp. simplex (Waldst. et Kit.) Nyman, Carlinaacanthifolia All. subsp. acanthifolia, Carduus nutans L. subsp. nutans, Carduus micropterus (Borbàs) Teyber subsp. perspinosus (Fiori) Kazmi, Cirsiumeriophorum (L.) Scop., Centaurea rupestris L. subsp. rupestris, Taraxacum laevigatum (Willd.) DC., Crepis lacera Ten., Veratrum nigrum L., Asphodelus albus Miller subsp. albus, Asphodelinelutea (L.) Reichenb., Colchicum lusitanum Brot., Gagea pusilla (F. W. Schmidt) Schult. et Schult. fil., Allium lusitanicum Lam., Allium fuscum Waldst. et Kit., Romulea bulbocodium (L.) Sebast. et Mauri, Carex flacca Schreber subsp. flacca, Xeranthemum inapertum (L.) Miller. A number of synanthropic species were also found, such as Lolium perenne L., Loliummultiflorum Lam., Plantago major L. subsp. major and Galactites tomentosa Moench, indicating a strong pressure on the plant community and possibly a misguided land use management.

Community interest habitats found within this landscape unit:

- Semi-natural dry grasslands and scrubland facies on calcareous substrates ( ${ }^{*}$ rich in orchids - code 6210);

- Pseudo-steppe with grasses and annuals of the Thero-Brachypodietea (code *6220);

- Lowland hay meadows (code 6510);

- Calcareous rocky slopes with chasmophytic vegetation (code 8210).

\section{Beechwoods}

Beechwoods represent the typical vegetation in the top-mountain belt of the Campanian Apennines. Given the limited height of the reliefs, the beechwoods in the study area fall within the lower zone of the beech tree (Trotter 1907). Beechwoods are found on both the main mountain reliefs from $900 \mathrm{~m}$ to $1350 \mathrm{~m}$ a.s.l. In the cacuminal belt trees show a shrubby habit, because of strong winds and severe summer drought.

Most of the beech stands are monospecific coppices. In some sectors with deeper, moist soils Acer lobelii Ten., Acer pseudoplatanus L. and Acer neapolitanum Ten. were found. In the transition zones dominated by chestnut, Acer obtusatum Willd. has also been found, while in the "Forestry Commission area" of Taburno the beech grows with Abies alba Miller, Larix decidua Miller, Picea abies (L.) Karsten, Pseudotsuga menziesii (Mirbel) Franco and a few other allochthonous species introduced in the 1846. Silver Fir (Abies alba) stands cover an area of about 40 ha.

The beechwood structure varies according to the combinations of environmental conditions resulting from altitude, exposure, soil depth and water content. Generally, two main types of beechwood may be observed: 1) the thermophilous stands at lower altitudes, which is less mature, more open and floristically richer with many species typical to the lower vegetation belt; 2) the mesohygrophilous stands, which is more mature, denser on the less steep slopes, more concentrated on Taburno. Many of the stands growing on Camposauro were more extensively exploited in the post-war period.

On Mt. Taburno the Common Holly (Ilex aquifoli$u m$ L.) is fairly abundant, so that the association was defined as Holly-Beech community (Aquifolio-Fagetum Gentile 1962, Caputo 1968). In the mesohygrophilous beechwood, low-growing holly is commonly found in the understorey both at the margin and within the beechwood. On Camposauro it has a more limited distribution, although we observed some trees that reached about 10 metres in height. Holly tree sizes tend to decrease in the marginal summital areas where it grows isolated.

In north-facing areas with fresh soils and a considerable amount of leaf litter, dense populations of bulbous species have developed, indicating fairly intense human activity in the past. This herbaceous layer is fairly rich in biomass, and is characterized by species common to the Campanian Apennines. Allium ursinum L. subsp. ursinum is dominant, forming broad, continuous, thick carpets. In areas with recent cuts Stachys sylvatica L. and Adenostyles glabra DC were found. In cooler, more sheltered areas we found Mercurialis perennis L., Cardamine bulbifera (L.) Crantz, Cardaminechelidonia L., Cardamine enneaphyllos (L.) Crantz, Cardamine graeca L., Asperula odorata L., Stellaria nemorum L. subsp. glochidisperma Murb. In areas where the canopy is less dense and in ecotonal areas we detected the rare Lilium martagon L., together with Digitalis ferruginea L., Veronica hederifo- 
lia L. subsp. hederifolia, Corydalis cava (L.) Schweigg. et Koerte subsp. cava, Corydalis pumila (Host) Reichenb., Atropa belladonna L., Daphne laureola L. subsp. laureola, Senecionemorensis L. subsp. fuchsii (C.C. Gmelin) Čelak., while in the areas close to the valleys with moister soil the rare Anemone ranunculoides L. was detected. On eroded soils Viola alba Besser subsp. denhardtii (Ten.) W. Becker and Viola reichenbachiana Boreau were found. In the lowest part of the beech belt on both Mt. Taburno and Mt. Camposauro bulbs were found such as Galanthus nivalis L. subsp. nivalis, Scilla bifolia L., Crocusvernus L. subsp. vernus which even expand throughout the chestnut woods. On the limestone outcrops within the beechwood typical rupicolous ferns were found such as Asplenium trichomanes L. subsp. quadrivalens D.E. Meyer, Aspleniumruta- muraria L. subsp. ruta-muraria, Polypodium vulgare L., Ceterach officinarum DC. and Asplenium onopteris $\mathrm{L}$.

At the margin of the beechwood, especially in south-facing summit areas, a thick belt of Pteridium aquilinum (L.) Kuhn subsp. aquilinum has developed where Lilium martagon L. is quite rare. Other species found in the beechwood are: Cystopteris fragilis (L.) Bernh., Dryopteris pallida (Bory) Maire et Petitm. subsp. pallida,Polystichum setiferum (Forssk.) Woynar, Aristolochia rotunda L., Aristolochia lutea Desf., Moehringia trinervia (L.) Clairv. subsp. trinervia, Allium triquetrum L., Polygonatum multiflorum (L.) All., Moehringia muscosa L. Stellaria holostea L., Circaea lutetiana L., Epilobium montanum L., Primula vulgaris Hudson subsp. vulgaris, Galium odoratum (L.) Scop., Pulmonaria vallarsae A. Kerner, Symphytumtuberosum L. subsp. angustifolium (A. Kerner) Nyman, Symphytum bulbosum C. Schimper, Scrophularia vernalis L., Scrophularia scopolii Hoppe, Scrophularianodosa L., Veronica hederifolia L. subsp. hederifolia,Lathraea squamaria L., Adoxa moschatellina L., Gagea lutea (L.) Ker-Gawl., Ornithogalumgussonei Ten., Polygonatumodoratum (Miller) Druce, Luzula sylvatica (Hudson) Gaudin subsp. sylvatica, Poa nemoralis L., Melica uniflora Retz. In the top ecotonal areas grows the very rare Rosa pimpinellifolia $\mathrm{L}$. and orchids such as Epipactishelleborine (L.) Crantz subsp. helleborine, Platantherachlorantha (Custer) Reichenb. Within the beechwoods Neottia nidus-avis (L.) L.C.M. Richard is almost rare. Finally, on the southern slope of Mt. Camposauro, at the lower margin of the beech forest there is a small population of Betula pendula Roth.

Community interest habitats found within this landscape unit:

- Apennine beech forests with Taxus and Ilex- (code
*9210);

- Apennine beech forests with Abies alba- (code *9220).

\section{Chestnut woods}

The chestnut stands cover only $7.1 \%$ of the whole park. Both coppices and fruit orchards are present within the area considered, though the latter was detected only in a small part of the sub-montane belt of Mt. Taburno. Generally, a compact grassy carpet occurs, consisting primarily of grasses such as the dominant Brachypodium rupestre (Host) Roemer et Schultes. Amongst the bulbous plants found, Galanthus nivalis L. subsp. nivalis, Crocus vernus L. subsp. vernus and Scilla bifolia $\mathrm{L}$. It has to be remarked the presence of Crocus imperati Ten., a species with a very limited distribution in the park, occurring only in a small areas at the margin of the chestnut forest. In this same sector, the locust tree Robinia pseudoacacia L. is also common and increasingly widespread together with Acer obtusatum Willd. Only in a small sector of the chestnut forest, at Pietra Pizzuta, there is a young (about 30 years) plantation of chestnuts with a high density, showing an average height of $15 \mathrm{~m}$ and a good vegetative status. The herbaceous layer is almost completely absent and the soil horizon $O$ has a fairly thick undecomposed litter about 6-8 $\mathrm{cm}$ deep and a humic layer of about $10 \mathrm{~cm}$. Sometimes Symphytum tuberosum L. subsp. angustifolium (A. Kerner) Nyman and Helleborus foetidus L. may be found.

The coppiced chestnut woods within the park may be grouped into short-rotation and long-rotation coppices. In short-rotation stands a marked presence of tree and shrub species like maple, black locust, rose and blackberry and a scant presence of herbaceous species was detected. In long-rotation woods, however, we found greater canopy homogeneity, shrubby species are concentrated at the margins, and herbaceous species typically found in chestnut stands (such as anemons, geraniums and cyclamens) are more common.

On Mt. Camposauro in an area called Favella, there is also a dense Pinus nigra plantation with tall trunks, and an understorey vegetation mainly composed by bracken (Pteridium aquilinum) and a few other shadetolerant species. In the area of Sazzarana on the Mt. Camposauro, a greater presence of other broadleaved species such as Acer pseudoplatanus L., Acer neapolitanum Ten., was found in long-rotation chestnut stands with height of about $15 \mathrm{~m}$. The understorey layer here is composed by Anemone apen- 
nina L. and Geranium nodosum L. with isolated spots of Pteridium aquilinum (L.) Kuhn subsp. aquilinum. In the less dense sectors and on margins, Viola aethnensis Parl. subsp. splendida (W. Becker) Merxm. et Lippert, Cyclamen repandum Sibth. et Sm., Cyclamenhederifolium Aiton and Primula vulgaris Hudson subsp. vulgaris were detected.

Community interest habitats found within this landscape unit:

- Castanea sativa stands (code 9260).

\section{Mixed mesophilous forests}

The mixed mesophilous forests are mainly located on north-facing slopes, are fairly homogeneous and the variations in density of some species depend more on geomorphology than on human factors. The mixed mesophilous stands are composed by many tree species, including Alnuscordata (Loisel.) Desf., Acer pseudoplatanus L., Quercus pubescens Willd., Acerobtusatum Willd., and Carpinus betulus L. The composition slightly changes along the streams, where Alnuscordata (Loisel.) Desf. and Corylus avellana L. are more abundant, with mature individuals (long rotations are mainly due to the difficulty of manoeuvring on the rough terrain). Laburnum anagyroides Medicus also occurs commonly on the margin of woodland. These stands are fairly old, thus favouring the presence of a rich understorey vegetation. In the moist valleys, a fairly large abundance of ferns was found, reaching here their maximum growth and species diversity, and including species like the uncommon Phyllitis scolopendrium (L.) Newman subsp. scolopendrium, Asplenium onopteris L., Asplenium trichomanes L. subsp. quadrivalens D.E. Meyer, Polypodium interjectum Shivas, Polypodium cambricum L. subsp. serrulatum (Sch. ex Arcang.) Pichi Serm., Cystopteris fragilis (L.) Bernh., Dryopteris filix-mas (L.) Schott, Polystichum setiferum (Forssk.) T. Moore ex Woynar. Common species found were: Humulus lupulus L., Hedera helix L. subsp. helix, Stachys sylvatica L., Anemone apennina L., Geranium robertianum L., Lunaria annua L. subsp. annua., Allium pendulinum Ten., Bromus ramosus Hudson, Rumex nebroides Campd., Vicia grandiflora Scop., Euonymus latifolius Miller, Viola odorata L., Viola suavis Bieb., Smyrnium perfoliatum L., Salvia glutinosa L., Arum italicum Miller subsp. italicum, Arum maculatum L.

Community interest habitats found within this landscape unit:

- Tilio-Acerion forests of slopes, screes and ravines (code ${ }^{* 9180) \text {. }}$

\section{Mixed xerophilous forests}

Mixed xerophilous forests are mainly distributed in the hill zone. At lower altitude, they occur together with the olive orchards that surround the whole foothill zone of both reliefs on the southern, eastern and western slopes. Xerophilous stands were classified according to the dominant species. In particular, based on the survey carried out, several typologies (phytocoenoses) may be distinguished: mixed woodland with downy oak dominant, mixed woodland of downy oak and turkey oak, mixed woodland of downy oak and manna ash, mixed woodland of downy oak and hop hornbeam, mixed woodland of holm oak and hop hornbeam. Most typologies refer to the phytosociological orders Quercetalia pubescentipetraeae Klika 1933 and Quercetalia pubescentis Klika 1933 and more precisely, to the alliances Quercion pubescenti-petraeae Br.-Bl. (1932); and Orno-Ostryon Tomazič 1940; some phytocoenoses should be referred to the order Quercetalia ilicis Br.Bl. ex Molinier 1934 em. Rivas- Martinez 1975 and to alliance Quercion ilicis Br.Bl. ex Molinier 1934 em. Brullo, Di Martino et Marcenò 1977.

Mixed woods with dominant downy oak (Quercus pubescens Willd.) were found from the hill up to the submontane belt, consisting more of scrub rather than trees. They stem from continuous human disturbance and long-time interventions aimed to replace them with woody crops, especially olives (as revealed by the many downy oaks growing in olive orchards), with an average height of 6-7 metres. The downy oak was found in association with Fraxinus ornus L. and Acer campestre L., rarely with Laurus nobilis L.. Among shrubs, the following species commonly occur: Asparagus acutifolius L., Crataegus monogyna Jacq., Coronilla emerus L., Cytisus sessilifolius L. and Clematis vitalba L. On limestone scree where the soil is less consolidated, woody species are even less frequent.

A common association found in this survey is mixed downy oak and turkey oak woodland, growing on the southern and eastern slope of the Camposauro group over a huge area of about 800 hectares. This coppiced woodland has a typically complex range of species including Quercus pubescens Willd., Quercus cerris L., and many tree species such as Fraxinusornus L., Ostrya carpinifolia Scop., Acer campestre L., Acer monspessulanum L., Sorbus aria L., Sorbus domestica L., and in zones with cooler soils, Carpinus orientalis Miller and Corylus avellana L. These stands are typically about 8-10 metres tall, sometimes reaching 12-13 metres in areas with 
longer rotation. Degraded forms are usually characterized by the presence of broom species, while the presence of the hop hornbeam and neutral-basic or weakly acidic shrubland of Prunetalia spinosae R. Tx. 1952 mantle is a hint of less degraded situations. Less common herbaceous species are Viola alba Bess. subsp. dehnhardtii (Ten.) W. Becker and Teucrium siculum Guss., usually found in southern Apennine holm-oak woods. Within the ecotonal areas with bush vegetation several rare Orobanche were found, such as Orobanche hederae Duby growing on Hedera helix L., Orobanche variegata Wallr. growing on Cytisus sessilifolius L. and Orobanche gracilis $\mathrm{Sm}$. growing on Cytisus sessilifolius L., on Coronilla emerus subsp. emerus and on Lotus corniculatus L.

The mixed xerophilous woodland composed by downy oak and manna ash is interesting and extensive (over 1000 ha of the park's territory). The most representative part grows on the southern slope of the Camposauro massif above the town of Frasso Telesino. This typology is fairly low-growing (always below 8 metres, with an average height of 6-7 metres), partly because it is managed with a short cropping rotation. Besides the very dense downy oak and manna ash, other thermophilous species were also found, including Quercus ilex L., Laurus nobilis L. and Acer campestre L.. The density of shrub species is very high, especially Myrtus communis L., Pistacia lentiscus L., Asparagusacutifolius L., Cistus incanus L., Cistus salvifolius L., Euphorbia cyparissias L., Euphorbia characias L., Lonicera caprifolium L., Lonicera etrusca G. Santi, Ruscus aculeatus L., Smilax aspera L., while Crataegus monogyna Jacq. and Rosa canina L. are less frequent. Herbaceous species list include Dactylisglomerata L., Galium murale (L.) All., Galium verum L. subsp. verum, Arabis turrita L., Brachypodium sylvaticum (Hudson) Beauv., Nigella damascena L.. The following species are also fairly common: Campanula persicifolia L. subsp. persicifolia, Campanula trachelium L. subsp. trachelium, Orlaya kochii Heywood, Asperula laevigata L., Scutellaria columnae, All. subsp. columnae, Melittismelissophyllum L. subsp. melissophyllum, Stachys officinalis (L.) Trevisan subsp. officinalis and Inulaconyza DC., which confirms the thermophilous characteristics of this plant community. Silene viridiflora L., Hypericum montanum L. and Lathyrus vernus (L.) Bernh. are rare, while Prunus avium L. and Cornusmas L. are uncommon.

Mixed woodlands of downy oak and hop hornbeam were less commonly found, as well as mixed holm oak and hop hornbeam woodland, being distributed in narrow, specific sectors on both reliefs.
They occur mainly on the near-vertical slopes with rough, fractured limestone cliffs. Such woodlands were found almost at the peaks beneath the beechwoods, which often stretch down south-facing slopes, with individuals showing a stubby shape. The two above types do not form homogeneous, uniform communities, but rather sparse woods of variable density closely linked to specific geomorphological and edaphic conditions. Spots of holm oak may occur in more sheltered areas with more hospitable soils, or spots of hop hornbeam may be found in steeper areas with very eroded, thin soils, suggesting its broad ecological value. The downy oak is rarer than the latter two species and appears as a feature of less steeply-sloping areas. Due to extensive human disturbance, these formations are extremely discontinuous, consisting of poorly developed plants that generally attain very small sizes compared to their counterparts on deeper soils. Of great interest is the herbaceous flora growing in these areas, while the shrub vegetation is fairly monotonous. The most common species are Asphodelus microcarpus Viv., Oenanthe pimpinelloides L., Cerastium glomeratum Thuill., Arabis hirsuta (L.) Scop., Cephalaria leucantha (L.) Roemer et Schult., Scabiosa uniseta Savi, Artemisia alba Turra, Hieracium florentinum All., Gladiolus italicus Miller, Pteridium aquilinum (L.) Kuhn subsp. aquilinum and Hieracium virgaurea Cosson.

At the margins of thermophilous woods the most common species are Campanula persicifolia L. subsp. persicifolia, Rubia peregrina L., Cynosurus echinatus L., Brachypodiumsylvaticum (Hudson) Beauv. subsp. sylvaticum, Avena barbata Potter subsp. barbata, Avena fatua L., Holcus lanatus L., Phleum pratense L. subsp. pratense, Piptatherum miliaceum (L.) Cosson subsp. miliaceum, Carex sylvatica Hudson subsp. sylvatica, Bellis annua L. subsp. annua, Bellisperennis L., Bellis sylvestris Cyr., Helianthus annuus L., Achillea millefolium L. subsp. millefolium, Chrysanthemum segetum L., Tussilago farfara L., Carduus pycnocephalus L. subsp. pycnocephalus, Ptilostemon strictus (Ten.) W. Greuter, Silybum marianum (L.) Gaertner, Cichorium intybus L., Urospermum dalechampii (L.) Scop. ex F. W. Schmidt, Tragopogonporrifolius L. subsp. australis (Jordan) Nyman, Crepis vesicaria L. subsp. vesicaria, Leopoldiacomosa (L.) Parl., Allium roseum L., Tamus communis L., Rubus ulmifolius Schott. and Foeniculum vulgare Miller subsp. piperitum (Ucria) Cout. Of interest is the presence of the Rosa sp. pl. on the southern slopes of Mt. Camposauro, especially at the margins of woods, like Rosa sempervirens L., Rosa arvensis Hudson, Rosa agrestis Savi, Rosa canina L., Rosaandegavensis Bast. 
Tab. 1 - Habitat types and their extension within the studied area. Priority habitats are marked by an asterisk $(*)$.

\begin{tabular}{lccc}
\hline \multicolumn{1}{c}{ Habitat } & $\begin{array}{c}\text { Natura 2000 } \\
\text { Code }\end{array}$ & $\begin{array}{c}\text { Area } \\
\text { (Ha) }\end{array}$ & $\begin{array}{c}\text { Habitat's } \\
\text { fragments }\end{array}$ \\
\hline $\begin{array}{l}\text { Semi-natural dry grasslands and scrubland facies on calcareous } \\
\text { substrates (Festuco-Brometalia- *important orchid sites) }\end{array}$ & 6210 & 557 & 55 \\
$\begin{array}{l}\text { Pseudo-steppe with grasses and annuals of the } \\
\text { Thero-Brachypodietea }\end{array}$ & $* 6220$ & 867 & 57 \\
Lowland hay meadows & 6510 & 259 & 31 \\
Calcareous rocky slopes with casmophytic vegetation & 8210 & 13 & 7 \\
Tilio-Acerion forest of slopes, screes and ravines & $* 9180$ & 1962.1 & 64 \\
Appendine Beech forests with Taxus and Ilex & $* 9210$ & 2444.9 & 20 \\
Appendine Beech forests with Abies alba and beech & $* 9220$ & 43 & 1 \\
Pannonian woods with Quercus pubescens & $* 91 \mathrm{H} 0$ & 2572.9 & 145 \\
Castanea sativa stands & 9260 & 901 & 25 \\
\hline
\end{tabular}

Community interest habitats found within this landscape unit:

- Pannonian woods with Quercus pubescens (code *91H0).

\section{Results}

\section{Habitat and species biodiversity}

Based on the survey carried out, nine community interest habitats were identified within the park's territory, five of which were priority. Four of these five priority habitats are forest communities, while the fifth is a herbaceous one. The extension of each habitat is reported in Tab. 1. The Shannon index calculated for the nine habitats was 1.73 , which is very high compared with the maximum index value. However, as in practice Shannon's index does not exceed 5 , the value obtained shows that there is signi- ficant biodiversity for the surveyed habitats. The parameter $\mathrm{E}_{\mathrm{SH}}$ (Shannon's evenness index) was equal to 0.78 , which is close to its maximum value, indicating that there is no habitats largely dominant over the others, i.e., which covers almost the whole park area. The graph in Fig. 3 displays the dominance-diversity relationship among the habitats identified. Habitats were sorted by decreasing extension as reported in Tab. 2. The graph shows that lower rank habitats have approximatively the same dominance value (expressed as the natural logarithm of their calculated dominance), while the curve drops down for higher rank habitats (especially for the last three habitats).

The largest habitat is the priority habitat ${ }^{*} 91 \mathrm{H} 0$ (Pannonian woods with Quercus pubescens) - accounting for 2572.9 ha (18.6\% of the whole park extension) in which downy oak and turkey oak are dominant.

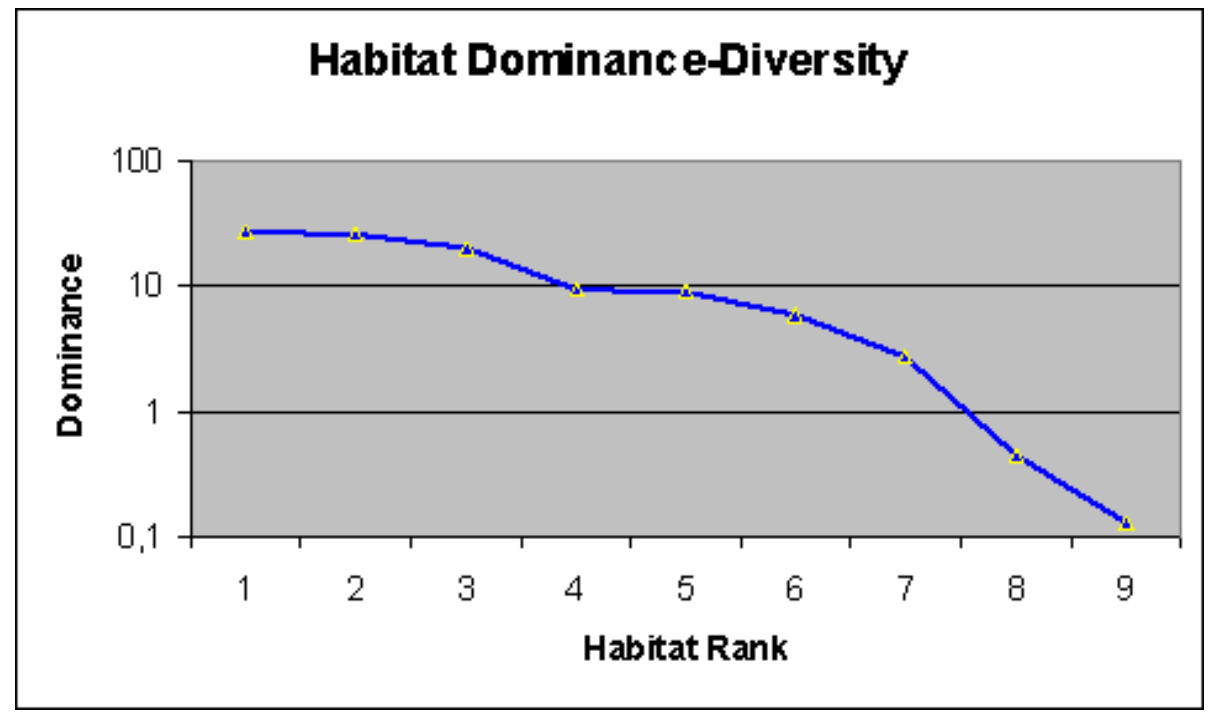

Fig. 3 - Relationship between dominance and diversity within the community interest habitats present in the park. 
Tab. 2 - Habitat dominance according to their extension within the studied area.

\begin{tabular}{cccc}
\hline Rank & $\begin{array}{c}\text { Habitat } \\
\text { code }\end{array}$ & $\begin{array}{c}\text { Extension } \\
\text { (Ha) }\end{array}$ & $\begin{array}{c}\text { Dominance } \\
\text { (\% of the whole } \\
\text { park surface) }\end{array}$ \\
\hline 1 & $* 91 \mathrm{H} 0$ & 2572 & 26 \\
2 & $* 9210$ & 2444 & 25 \\
3 & $* 9180$ & 1962 & 20 \\
4 & 9260 & 901 & 9 \\
5 & $* 6220$ & 867 & 9 \\
6 & 6210 & 557 & 5 \\
7 & 6510 & 259 & 2 \\
8 & $* 9220$ & 43 & 0 \\
9 & 8210 & 13 & 0 \\
\hline
\end{tabular}

Habitat *9210 (Apennine beech forests with Taxus and Ilex) accounting for 2446 ha (about $17 \%$ of the whole park). It is also the forest habitat with the richest flora. Habitat 9260 (Castanea sativa stands) covers $6.5 \%$ and habitat ${ }^{*} 9180$ (Tilio-Acerion forests of slopes, screes and ravines, also a priority habitat) covers $12.6 \%$. The rarest habitat (of human origin) is *9220 (Apennine beech forests with Abies alba and Beech, also a priority habitat) which accounts for 43.7 ha. The smallest habitat is 8210 (Calcareous rocky slopes with chasmophytic vegetation) with only 13.2 hectares.

Overall, community habitats cover an area of 96.2 $\mathrm{km}^{2}(70.2 \%$ of the whole park territory) and priority habitats alone account for $78.9 \mathrm{~km}^{2}$ (82\% of total area of the habitats and $57.5 \%$ of the whole park).

Tab. 3 - The most relevant plant species of the Taburno-Camposauro Regional Park (chorotype classification after Pignatti 1982).

\begin{tabular}{ll}
\hline \multicolumn{1}{c}{ Specie's name } & \multicolumn{1}{c}{ Chorotype } \\
\hline Acer lobelii Ten. & Endemic - only South Italy \\
Acer neapolitanum Ten. & Endemic - South Italy \\
Alnus cordata (Loisel.) Loisel. & Endemic - South Italy \\
Avenula praetutiana (Parl.) Pignatti & Endemic - Middle-South Italy \\
Campanula tanfanii Podl. & Endemic - Middle Italy still to Campania \\
Cardamine chelidonia L. & Endemic - Italy \\
Carduus micropterus (Borbás) Teyber subsp. perspinosus & Endemic - Middle-South Italy \\
(Fiori) Kazmi & Endemic - Middle-South Italy \\
Cerastium scaranii Ten. & Endemic - Middle-South Italy \\
Crepis lacera Ten. & Endemic - only Campania-Basicata-Calabria \\
Crocus imperati Ten. & Endemic - Italy \\
Digitalis micrantha Roth & Endemic - Middle-South Italy \\
Echinops siculus Strobl & Endemic - Middle Italy \\
Erysimum pseudorhaeticum Polatschek & Endemic - Middle-South Italy \\
Festuca robustifolia Markgr.-Dannenb. & Endemic - Campania \\
Globularia neapolitana O. Schwarz & Endemic - Middle-South Italy \\
Hieracium virgaurea Cosson & Endemic - Middle + Campania \\
Ionopsidium savianum (Caruel) Arcangeli & Endemic - Middle-South Italy \\
Knautia calycina (C. Presl.) Guss. & Endemic - Middle-South Italy \\
Linaria purpurea (L.) Miller & Endemic - Middle-South Italy \\
Myosotis ambigens (Béguinot) Grau & Endemic - Middle + Campania \\
Myosotis decumbens Host subsp. florentina Grau & Endemic - Middle-South Italy \\
Phleum ambiguum Ten. & Endemic - Italy \\
Polygala flavescens DC. & Endemic - Italy \\
Pulmonaria vallarsae A. Kerner & Endemic - Middle + Campania \\
Rhinanthus personatus (Behrendsen) Béguinot & Endemic - Middle-South Italy \\
Salix apennina A. Skvortsov & Endemic - Italy \\
Scabiosa uniseta Savi & Endemic - Middle-South Italy \\
Solenanthus apenninus (L.) Fischer et C. A. Meyer & Endemic - Italy \\
Teucrium siculum (Rafin.) Guss. & \\
\hline
\end{tabular}


Tab. 4 - List of the Orchidaceae species found in the Taburno-Camposauro Regional Park.

\begin{tabular}{l}
\hline \multicolumn{1}{c}{ Species name } \\
\hline Aceras antropophorum (L.) R. Br. \\
Anacamptis pyramidalis (L.) L.C.M. Richard \\
Cephalanthera damasonium (Miller) Druce \\
Epipactis helleborine (L.) Crantz subsp. helleborine \\
Gymnadenia conopsea (L.) R. Br. \\
Limodorum abortivum (L.) Swartz \\
Neottia nidus- avis (L.) L.C.M. Richard \\
Ophrys apifera Hudson \\
Ophrys bombyliflora Link \\
Ophrys fuciflora (F.W. Schmidt) Moench \\
Ophrys incubacea Bianca \\
Ophrys sphegodes Miller subsp. sphegodes \\
Ophrys tenthredinifera Willd. \\
Orchis italica Poiret \\
Orchis mascula L. \\
Orchis morio L. \\
Orchis papilionacea L. \\
Orchis pauciflora Ten. \\
Orchis provincialis Balbis \\
Orchis purpurea Hudson \\
Orchis simia Lam. \\
Orchis tridentata Scop.. \\
Orchis ustulata L. \\
Platanthera chlorantha (Custer) Reichenb. \\
Serapias lingua L. \\
Serapias vomeracea (Burm.) Briq.
\end{tabular}

Some 997 plant species were identified and classified by this survey, 29 of which (including 4 forest species) are strictly endemic or stenochorous (Tab. $3)$. The species list displayed in table 3 has been extrapolated from the list of the flora of the park and the chorotipes have been obtained from the specific scientific literature (Pignatti 1982). The most exclusive endemism is Globularia neapolitana O. Schwarz which occurs only in Campania (recorded only in the Sorrentine peninsula); the range of Crocus imperati Ten. (Campania, Basilicata and Calabria) is also somewhat narrow, as that of Acer lobelii Ten. (Marche, Molise, Campania, Basilicata and Calabria); the range of Acer neapolitanum Ten. is only slightly larger (from Lazio to Calabria). All other species have a wider distribution, in several cases extending throughout Italy, with few regions excluded. The most common endemisms of the park are present in the central and southern part of Italy. Some of the endemic species are included in the red list of en- dangered plants in Campania. Despite these species have commonly a patchy distribution, they are fairly abundant in the protected area considered. The exceptions are Crocus imperati Ten. and Acer lobelii Ten., which is the reason they were considered the most endangered species in the protected area.

Some 26 species of orchids were found in the park territory (Tab. 4). Many of these are included both on the red list of endangered plants in Campania and on the list of protected flora in Italy. Some of them are fairly rare, such as Neottia nidus-avis (L.) L.C.M. Richard, growing in beechwoods, Ophrys bombyliflora Link and Ophrys incubacea Bianca in meadows.

A full list of the species included in the red list of endangered plants in Campania (Tab. 5) was drawn up according to the findings of Conti et al. (1997). Of the 14 species listed, the forest species Betula pendula Roth is currently under serious risk since it is represented within the park by a small population of a few individuals. The other two tree species, namely Abies alba Miller and Pinus nigra Arnold subsp. nigra, were maily found within the re-afforestation areas. As for the herbaceous species in the red list, many of them are characterized by very small populations within the park, and therefore are prone to local extinctions. Crocus imperati Ten. is at very great risk, growing in only one small area in the chestnut wood. The populations of Lilium martagon L. are also very limited, though the species has been found in several beechwood stands. Plantago subulata L. has a distribution limited to a single sector of Mt. Camposauro with a fairly large population, though the area is grazed by cattle. The same situation holds for Dianthus balbisii Ser. subsp. balbisii, since it grows in a small population in woodland clearings and is commonly grazed by cattle. The other species are characterized by larger populations scattered over several sites in the park, and therefore their status does not appear prone to local extinction.

Within the park territory, many species listed under protected flora of Italy (24 species) drawn up by the Ministry of the Environment and Land Conservation were found (Tab. 5). The list is dominated by Orchidaceae, including many Orchis and Ophrys species, and includes also Ruscus aculeatus L., although the species occurs widely in all thermophilous woods in the protected area.

Although the above mentioned species are officially endangered, there are also 13 other species in the park which, though not appearing on the red data list, have a fairly limited distribution within the protected area, and whose local extinction would 
Tab. 5 - (A) Species of Taburno-Camposauro Regional Park featuring in the Red List of plants at risk of extinction in Campania; (B) Species listed as Italian protected flora.

\section{(A) Risk of extinction}

Asplenium ceterach L. subsp. bivalens (D. E. Meyer)

Greuter et Burdet

Abies alba Miller

Betula pendula Roth

Crocus imperati Ten.

Dasypyrum villosum (L.) P. Borbás

Dianthus balbisii Ser. subsp. balbisii

Globularia neapolitana O. Schwarz

Hepatica nobilis Schreber

Ionopsidium savianum (Caruel) Arcangeli

Lilium martagon L.

Pinus nigra Arnoldsubsp. nigra

Plantago subulata L.

Potentilla detommasii Ten.

Stipa dasyvaginata Martinovský subsp. appenninicola

Martinovský et Moraldo

\section{(B) Protected Species}

Galanthus nivalis L. subsp. nivalis

Gymnadenia conopsea (L.) R. Br.

Jonopsidium savianum (Caruel) Arcangeli

Limodorum abortivum (L.) Swartz

Neottia nidus-avis (L.) L.C.M. Rich.

Ophrys apifera Hudson

Ophrys bombyliflora Link

Ophrys fuciflora (F.W. Schmidt) Moench

Ophrys incubacea Bianca

Ophrys sphegodes Miller subsp. sphegodes

Ophrys tenthredinifera Willd.

Orchis italica Poiret

Orchis mascula (L.) L.

Orchis morio L.

Orchis papilionacea L.

Orchis pauciflora Ten.

Orchis purpurea Hudson

Orchis simia Lam.

Orchis tridentata Scop.

Orchis ustulata L.

Platanthera chlorantha (Custer) Reichenb.

Ruscus aculeatus L.

Serapias lingua L.

Serapias vomeracea (Burm.) Briq.

significantly reduce the park's biodiversity. In Tab. 6, 13 species with rarity index (IR) larger than 90 are reported, including the endemic Acer lobelii Ten., which grows in small areas in the meso-hygrophilous beech forest, each of which consists of very few individuals or even of isolated individuals; it is found more commonly on Mt. Camposauro than on Mt. Taburno. Along with Lobel's Maple is Tiliaplatyphyllos Scop. consisting of a small relic population close to the chestnut forest in an area of Mt. Camposauro and subject to considerable human activity, and Celtis australis L. at the lower margin of the chestnut wood in a rural area of Mt. Taburno.

A herbaceous species with a particularly limited distribution is Lilium bulbiferum L. subsp. croceum (Chaix) Baker which grows in fairly exposed areas on the southern slope of Mt. Camposauro (it is rarer on Mt. Taburno). Even more limited is the distribution of Pseudolysimachion spicatum (L.) Opiz, found in a single site at the top of Mt. Taburno in a less human-disturbed environment (though still used for pasturage). Sternbergia lutea (L.) Ker-Gawl., is even rarer, growing in only one site on Mt. Taburno on some débris on the edge of a small Castaneasativa Miller stand with Acer obtusatum Willd. Near the stand of Sternbergia lutea (L.) Ker-Gawl. grows another species very rare in the park, Hyssopus officinalis L. subsp. officinalis (given the location of the site and its distance from urban areas, it was undoubtedly considered as a natural population). The park has none of the priority species listed in Annex 1 of Directive $92 / 43$.

\section{Suggestions for biodiversity conservation within the park}

\section{General considerations}

The present survey is mainly focused on biodiversity of the park and on species requiring special attention to ensure their future survival in the area. To this aim, it is essential an appropriate protection and management of habitats, which constitute a 
biodiversity conservation issue per se and which are playing an increasingly multi-functional role in protected areas. Policy guidelines drawn from current habitat conservation laws were calibrated on the species that today appear most threatened. Law nr. 394/1991 on the National Parks which was transposed within the Campania Regional Law nr. 33/1993 declares that the purpose of parks consists in conserving plant species and habitats, and should be pursued through the application of appropriate management or restoration methods. In addition, the Presidential Decree nr. 357 of 8 September 1997 establishes the adoption of procedures to conserve biodiversity by conserving natural habitats, either by the use of specific management plans or by integrating them with others managing tools matching the ecological needs of natural habitat types.

Based on the observations carried out during the survey, we suggest a strategy aiming at both the reduction of direct and indirect human pressure on the park's plant resources and a more "naturalistic" management of the habitats. This may be pursued through a series of activities that may be summarised as follows:

- Ensuring the stability of forest populations and rare species in terms of quality and quantity. The former may be pursued by the conservation of native species, the latter by increasing their population size.

- Eliminating undesired, exotic species, especially in the environments with a higher degree of naturality, where their presence may compromise natural forest dynamics.

- Regulating pasturage by shifting suitable areas for livestock according to altitude, floral composition, plant phenology and biomass production. Temporary set-aside of pasture areas with plant species with small endangered populations may be used as an extreme solution.

- Identifying long-time fire-free woodlands and grasslands as they are likely to maintain larger populations of rare and exclusive species.

- Protecting the forest soil from erosion, especially on steeply sloping reliefs, with naturalistic engineering.

- Reconstructing severely degraded habitats by the use of local species.

- Preventing forest depletion caused by visitors.

- Launching awareness courses on nature conservation, with special emphasis on rare species surviving in the park area.
Tab. 6 - Rare species of Taburno-Camposauro Regional Park with a localised and/or punctiform distribution. R: rare species; MR: very rare species; RR: extremely rare species.

\begin{tabular}{lcc}
\hline \multicolumn{1}{c}{ Specie's name } & $\begin{array}{c}\text { Rarity index } \\
\text { Value }\end{array}$ & Rarity \\
\hline Acer lobelii Ten. & 92.7 & $\mathrm{R}$ \\
Anemone ranunculoides L. & 97.0 & $\mathrm{MR}$ \\
Betula pendula Roth. & 98.5 & $\mathrm{RR}$ \\
Celtis australis L. & 98.5 & $\mathrm{RR}$ \\
$\begin{array}{l}\text { Hyssopus officinalis L. subsp. offi- } \\
\text { cinalis }\end{array}$ & 98.5 & $\mathrm{RR}$ \\
Iberis umbellata L. & 96.5 & $\mathrm{R}$ \\
Lilium bulbiferum L. subsp. cro- & 92.7 & $\mathrm{R}$ \\
ceum (Chaix) Baker. & & \\
Neottia nidus-avis (L.) L.C.M. & 92.7 & $\mathrm{R}$ \\
Richard & 97.0 & $\mathrm{MR}$ \\
Ophrys bombyliflora Link & 92.7 & $\mathrm{R}$ \\
Ophrys incubacea Bianca & 99.2 & $\mathrm{RR}$ \\
$\begin{array}{l}\text { Pseudolysimachion spicatum (L.) } \\
\text { Opiz }\end{array}$ & 98.5 & $\mathrm{RR}$ \\
Sternbergia lutea (L.) Ker-Gawl. & 98.5 & $\mathrm{RR}$ \\
\hline Tilia platyphyllos Scop. &
\end{tabular}

\section{Specific measures of intervention for conservation}

Among forest tree species requiring protection measures, Betula pendula Roth. is seriously endangered, growing in a small area on a north-facing, steep slope with eroded soil, close to an open-air area equipped with recreational facilities: its branches are often used as firewood, occasionally leading to tree death. Active intervention proposed: reafforestation with individuals taken in loco; passive intervention proposed: creation of educational panels giving information on the rarity of the species within the park. Acer lobelii Ten. requires a different strategy, in that it occurs close to the margins of the beech forest in less favourable conditions, e.g., roadside embankments characterized by deep erosion. Measures should be taken to reinforce its presence, especially where the wood is sparse. Tilia platyphyllos Scop. also requires active interventions, being menaced by continuous regression which may be halted only by repopulation, to be carried out by using propagation material taken in loco, cultivated in a nursery and planted in the area. The same holds for Celtis australis L.

To improve habitat conservation it is necessary to increase forests stability. The protection actions must be realized with low impact techniques especially in 
the areas where environmental biological and physical conditions are unstable. The first action is to increase soil stability consolidating slope with bio-engineering works against the water erosion processes. Moreover, for small, endangered forest populations it is necessary to increase the number of trees through plantation of local material. As for coppices, it is necessary to reduce their density and increase the number of seed plants. In areas with good environmental conditions it is possible to coppice conversion is recommended. It seems also necessary to carry out new plantations in degraded coppices to rapidly increase their density and stability, and reducing soil erosion. Furthermore, it is necessary to plan actions to decrease the number of fires all over the area.

Seriously endangered herbaceous species include Crocus imperati Ten. which grows in a single restricted area in the chestnut forest close to a small parking area and on a brief roadside stretch. Creating barriers hampering vehicle access seems the most effective active intervention to protect the above sites. The situation of Lilium martagon L. is equally problematic, albeit different. It is found in areas along footpaths in the beechwoods and along its upper margins in north-facing or sheltered sites. For the latter habitats, the maintenance of stable habitat conditions is suggested, while for the former the creation along the paths of panel reporting information on the species is recommended. The condition of Lilium bulbiferum L. subsp. croceum (Chaix) Baker. is even more critical, growing mainly in small areas characterized by high disturbance. The conservation strategy suggested above for Lilium martagon L. are also recommended for this species. Issues concerning Plantago subulata L. are mainly linked to pasturage, which stretches from the nearby carstic plain up to the peaks where it grows. As a conservation measure it would appear appropriate to prevent grazing at the site or at least reduce its frequency in time.

The general situation of Pseudolysimachion spicatum (L.) Opiz. within the park is worse. Its population is very small due to pasturage which has led to a decline in numbers as a result of mechanical damage rather than livestock preferences. As the area in which the species grows is very restricted and the number of plants is extremely low, the area requires at least temporary fencing to allow the population to reach a sufficiently large number of individuals to ensure its survival. The condition of Sternbergia lutea (L.) Ker-Gawl. is also very concerning: although its population is limited to a few hundred square meters, it does not seem threatened by pasturage. Conservation of this species within the park is strictly linked to the existence of local microenvironmental conditions, i.e., trees within the coppice whose crown shades the population of Sternbergia lutea (L.) Ker-Gawl. Anemone ranunculoides L. occurs at several sites in the park, albeit with disjunct areas: it grows in beechwoods close to escarpments with sparser vegetation. Avoiding pasturage in the plant's growth phase could be effective and easy to apply, given that the species has a fairly short life cycle. Despite their fairly limited distribution in the park, Ophrys bombyliflora Link and Ophrys incubacea Bianca do not require special protection measures as they already grow in fairly protected areas.

Finally, among the other species with a very limited distribution there is Hyssopus officinalis L. subsp. officinalis, often confused with a very similar species, Satureja montana L. There are very few individuals of this species, severely competing with Asphodelus microcarpus $\mathrm{L}$. which is dominant throughout the scree slope. The population is also fairly small, but an intervention to reduce the spread of the asphodel could ensure its conservation.

\section{Conservation of habitats}

The high biodiversity degree of the park is clearly highlighted by the values of the Shannon index and the rarity of species from the rarity index calculated for the 12 species with very limited distribution (Tab. 6). The habitats which have greater concentrations of rare species and protected species, and for which protection measures are needed to ensure their conservation are the beechwoods and the grassland formations. In the former, there are both tree and herbaceous species to be protected, while the latter has many herbaceous species and not only Orchidaceae. In the beech forest Acer lobelii Ten. and Betula pendula Roth. are quite rare. Although their presence is very significant, in the area also there are some endemisms or species in the red data book of endangered species in Campania or in other protected lists, whose status gives no cause for concern, such as Acer neapolitanum Ten. and Abies alba L. The grassland habitats are the areas hosting most of the orchids and some of the species with punctiform distribution.

Some 107 of the 997 species (i.e., about $11 \%$ of the park's entire flora) are exclusive, rare and hence worthy of greater attention for protection. In the red data book of endangered species in Campania there are 3 endemisms, 3 forest species, 10 herbaceous spe- 
cies including two bulbous plants. Of the species listed among Italy's protected flora there are 19 Orchidaceae but no endemism or plant on the red data list. In the list of the park's rare species there is 1 endemic, 4 forest species, 3 Orchidaceae, 5 bulbous and a shrub species.

Of the four forest species indicated as rare species, Tilia platyphyllos Scop and Celtis australis L. are undoubtedly those that have been mostly spoiled, as there are only relic populations left at two sites in the park. These species should be reintroduced in the park to re-constitute a self-sustaining wood as a starting-point for a recolonisation process.

\section{References}

Blana H (1980). Rasterkartierung und Bestandsdichterfassung von Brutvögeln als Grundlage für die Landschaftsplannung - Ein Vergleich beider Methoden im selben Untersichungsgebiet. In: Oelke H. (red.). Bird census work and nature conservation. Dachverbandes Deutscher Avifaunisten, Lengede: 32-54.

BURC (1993). Regional Law No. 33 of 01-09-1993 (No. 39). Istituzione di Parchi e riserve naturali in Campania.

Caputo G (1968). Ricerche sulla vegetazione forestale del Taburno-Camposauro. Delpinoa New Series 8-9: 91-134.

Conti F, Manzi A, Pedrotti F (1997). Liste rosse regionali delle piante d'Italia. Dipartimento di Botanica ed Ecologia, Università di Camerino, Camerino.

Corine Biotopes Manual - Habitats of the European Community (1991). EUR 12587/3. Office for official Publications of the European Communities.

D'Argenio B (1963). Lineamenti tettonici del gruppo del Taburno-Camposauro (Appennino Campano). Atti Acc. Pontaniana 13:1-27.

D'Argenio B (1967). Geologia del gruppo del TaburnoCamposauro (Appennino Campano). Atti Acc. Sc. Fis. e Mat.di Napoli, s. 3, 6(2): 35-218.

EUR 15-2 (2003). Interpretation manual of European Habitats. Office for official Publications of the European Communities 04/10/1999.

GUL no 206 (1992). EC Directive No. 43 of 21-05-1992. EC Directive $92 / 43$ on the conservation of natural and seminatural habitats, and of wild fauna and flora.

GU Repubblica Italiana No 292 (1991). S.O. Law no. 394 of 06-12-1991 on protected areas.
GU Repubblica Italiana No 248 (1997). DPR N o. 357 of 0809-1997. Regulation transposing Directive 92/43/EEC concerning the conservation of natural and semi-natural habitats, and of wild fauna and flora. Ordinary supplement.

Gentile S (1962). Notizie preliminari sulle faggete dell'Appennino Calabro. Delpinoa n.s., 4: 305-316.

Gentile S (1969). Sui faggeti dell'Italia Meridionale. Atti Ist. Bot. Univ. Pavia, Serie 6(5): 207-306.

Gotmark F, Ahlund M, Eriksson MOG (1986). Are indices reliable for assessing conservation value of natural areas? An avian case study. Bio. Conservation, 38: 55-73.

Guarino C, Napolitano F (2003). Un Sistema Informativo Territoriale per la Carta della Vegetazione della Provincia di Benevento. Documenti del Territorio 54: 44-47.

Guarino C, Napolitano F, Spadaro V (2003). The officinal flora of Sannio (Benevento, SE - Italy). Bocconea (OPTIMA) 15: 1-165.

Hydrologic Annals (1999). Ufficio Mareografico e Oceanografico di Napoli, Anni 1969-99. Istituto Poligrafico dello Stato, Libreria - Roma.

Lapini L, Lebboroni M, Sposimo P, Tellini G (1994). Un esempio di valutazione ambientale su base ornitologica. Atti del 117 Convegno Italiano di Ornitologia. Mus. Reg. sci. Nat. Torino:555.

Mingozzi T, Brandmayr P (1991). L'evaluation cartographique des resources faunistiques un exemple appliqué aux ornithocenoses d'une vallée alpestre. Revue Ecol. Alp., 1 (1): 1-21.

Ministero dell'Ambiente (2000). Manuale delle linee guida per la redazione dei piani di gestione dei siti natura 2000.

Ministero dell' Ambiente (2001). Repertorio della flora italiana protetta. Roma

Pignatti S (1982). Flora d'Italia. Edagricole, Bologna.

Tenore M (1838). Flora neapolitana, vol. 1-5. Napoli, Italia.

Tenore M (1842). Silloge plantarum vascularium florae neapolitanae. Napoli, Italia.

Terracciano N (1878). Quarta relazione intorno alle peregrinazioni botaniche fatte nella provincia di Terra di Lavoro. Caserta.

Trotter A (1907). La fitogeografia dell'Avellinese. Proceedings of the Italian Naturalists Congress. Soc. It. Nat., Milano.

Tutin TG, Burges NA, Charter AO, Edmondson JR, Heywood VH, Moore DM, Valentine DH, Walters SM, Webb DA (1993). Flora europea. Cambridge University Press. 